\title{
DEVELOPMENT OF MSW COLLECTION SERVICES ON REGIONAL SCALE: SPATIAL ANALYSIS AND URBAN DISPARITIES IN NORTH-EAST REGION, ROMANIA
}

\section{FLORIN-CONSTANTIN MIHAI}

\author{
"Alexandru Ioan Cuza" University, Faculty of Geography and Geology, Carol I, Blvd. 20 A, \\ 700505, Iasi, Romania \\ E-mail: mihai.florin86@yahoo.com
}

Received 10 December 2012, accepted in revised form17 May 2013

\begin{abstract}
The cities are facing illegal dumping of municipal solid waste (MSW) because the waste collection facilities do not cover the entire population. Furthermore, this sector is poorly developed in small towns or villages annexed to administrative territory units (ATU) of cities, MSW are disposed in open dumps polluting the local environment. This paper analyzes on the one hand the urban disparities on public access to waste collection services (WCS) in the North-East Region on the other hand, it performs a comparative analysis between 2003 and 2010 outlining the changes made in the context of Romania's accession to EU. Also, it performs a quantitative assessment method of uncollected waste at urban level and correlated to demographic features of each city. Spatial-temporal analysis of waste indicators using thematic cartography or GIS techniques should be a basic tool for environmental monitoring or assessment of projects from this field in every development region (NUTS 2). The EU acquis requires the closure of noncompliant landfills, the extension of waste collection services, the development of facilities for separate collection, recycling and reuse according to waste hierarchy concept. Full coverage of urban population to waste collection services is necessary to provide a proper management of this sector. Urban disparities between counties and within counties highlights that current traditional waste management system is an environmental threat at local and regional scale.
\end{abstract}

Keywords: waste collection, urban areas, disparities, regional scale

\section{Introduction}

Municipal waste collection services must be continuously adapted to growing urban areas. These services are a basic condition in order to provide a proper urban environment. EU regulations impose the separate collection vs. mixed waste collection which unfortunately still prevails in current urban waste management systems from Romania. Also, several EU newcomers is facing the challenges concerning the improvement of this sector (Mihai and Apostol, 2012; Koci and Trecakova, 2011; Alwaeli, 2010; Orosz and Fakezaz, 2008). Low coverage of waste collection services (WCS) led to illegal dumping of uncollected waste on improper sites. The extension of these services is emerging since the Romania's accession to EU-27 in 2007 but major disparities are reflected between Romanian counties during 2003-2008 (Mihai et al., 2012a; Mihai, 2012a).

\section{Methods}

The waste collection services rate (WCS $\%$ ) was calculated for each city based on informations provided by Bacău - Regional Environmental Protection Agency for 2010 and also from regional waste management 
Table 1. Per capita waste generation indicator (Ig) related to demographic features of cities

\begin{tabular}{rcc}
\hline Urban population & $\begin{array}{c}\text { Ig 2003 } \\
\text { (kg/inhab./day) }\end{array}$ & $\begin{array}{c}\text { Ig 2010 } \\
\text { (kg/inhab./day })\end{array}$ \\
\hline$<10000$ & 0.6 & 0.635 \\
$10000-50000$ & 0.7 & 0.74 \\
$>50000-100000$ & 0.8 & 0.85 \\
$>100000$ & 0.9 & 0.95 \\
$>300000$ & 1 & 1.06 \\
& $0.8 \%$ annual increase of $\mathrm{Q}_{\mathrm{hw}}$ \\
\hline
\end{tabular}

plan of North-East region for 2003 (RWMP, 2006). These data have been mapped at urban scale using the base map of administrative territorial units (ATU). Spatiotemporal analysis between pre-accession period (2003 - when old traditional waste management systems prevailed in all cities from region) and on the other hand, the current situation from post-accession period (2010 - waste management sector is facing the transition to a sustainable approach) reveals the gaps of waste policies from international to local scale. The paper aims to estimate the amounts of uncollected household waste $\left(Q_{\text {wu }}\right)$ applied at local scale related to demographic features of each city. This approach uses different values of waste generation indicator $\left(\mathrm{I}_{\mathrm{g}}\right)$ according to Table 1 .

The $Q_{w u}$ indicator is calculated applying the following formula: $\mathrm{Q}_{\mathrm{wu}}(\mathrm{t} / \mathrm{yr})=\mathrm{Pu}^{*} \mathrm{I}_{\mathrm{g}}$ *365/1000, $\mathrm{P}_{u}$ - urban population unserved by WCS (nr.). This approach is more proper at regional and local scale than applying an overall average value of Ig at Romanian counties level used by Mihai et al., (2011) respectively $0.8 \mathrm{~kg} /$ per capita/day in urban areas. Also, waste management plans use an overall average value for Ig of $0.9 \mathrm{~kg} / \mathrm{per}$ capita/day stipulating an annual increase of household waste $\left(Q_{h w}\right)$ by $0.8 \%$ from 2003. These averages are the only tools so far in order to estimate the amounts of waste generated by a region, county, city or commune because the lack of weighing systems from old waste management facilities and on the other side, due to poor quality of data provided by waste operators at ATU level. However, new methodologies are applied on waste statistics due to EU regulations which should lead to more accurate data in following years.

Furthermore, the new integrated waste management systems have implemented weighing systems in order to monitor the waste streams (e.g. Piatra Neamt city). Spatial analysis of waste indicators at ATU level is a necessary tool for assessment of waste management sector in various geographical areas (Mihai, 2012b). The data are mapped using color range for percentage values (WCS) and proportional circles for absolute values $\left(Q_{w u}\right)$. Stable population data from National Statistics Institute (NIS) are overestimated for the period 2003-2010 because of external migrations. Most of waste operators rely on these estimates and not by effective number of stable population derived from individual contracts. These inaccuracies have repercussions on the coverage rate of WCS in 2010. Most inhabitants are connected to such services in reality than number of people resulted from waste statistics. In this context, new data from Population Census (PC_2011_ preliminary data) are used to recalculate the coverage rate of the urban population and $Q_{w u}$ indicator for 2010. It is noted that most cities from study area have extended the coverage rate from 2003 and diminished the values of $\mathrm{Q}_{\mathrm{wu}}$ indicator following the application of this corrective measure. Comparative analysis between two demographic data (NIS_2010 vs PC_2011) outlines the differences regarding the $\mathrm{Q}_{\mathrm{wu}}$ indicator. 


\section{Results and discussion}

Old waste management systems from pre-accession period (2003-2006) favored landfilling and mixed waste collection. Public sector prevailed in almost all waste collection systems from study area. The cities weren't full covered by these services and only few urban areas had a rate more than 90\% in 2003 such as Siret, Bacău, Slănic Moldova (touristic resort) Târgu Frumos and Huși. The worst situation was in case of small cities where poor waste collection services prevailed and coverage rates were under 50\% (Dărăbani , Săveni, Câmpulung Moldovenesc, Negrești). Furthermore, the communes (red ones) had no waste facilities in 2003, these areas were declared cities in 2004-2006. In this context, waste dumping on improper sites was a common practice in these areas, threatening the human health and damaging the local environment. Extension of WCS from cities was accelerated by the transposition of $\mathrm{EU}$ acquis into national regulations. Reorganization of WCS and their transfer to private sector (mainly in the last years) have led to dynamic changes on this field, reflected also by coverage rates of urban population. Most of cities have improved their WCS rates compared to 2003 and also the new urban areas have implemented such services. However, some cities had low values (\%) în 2010 compared to 2003 respectively Dărăbani (21/42.9), Paşcani (63/66.4), Huşi (54.5/100), Negrești $(36.72 / 40.3)$ or the same coverage rate for both years such as Târgu Neamț (53\%). These urban areas are vulnerable to waste dumping along with other cities with coverage rates less than $70 \%$ such as Tg. Ocna (67\%), Bucecea (44\%), Câmpulung Moldovenesc (57.35\%) and Solca (59\%).

The overvaluation of stable population (which includes the citizens working abroad) have most influenced the real level of coverage rates from urban areas of Neamț and Vaslui counties. These rates are underestimated according the NIS database for 2010, comparative analysis $\left(2003 / 2010_{\text {_ }}\right.$ NIS/2010_PC\%) reveals the following

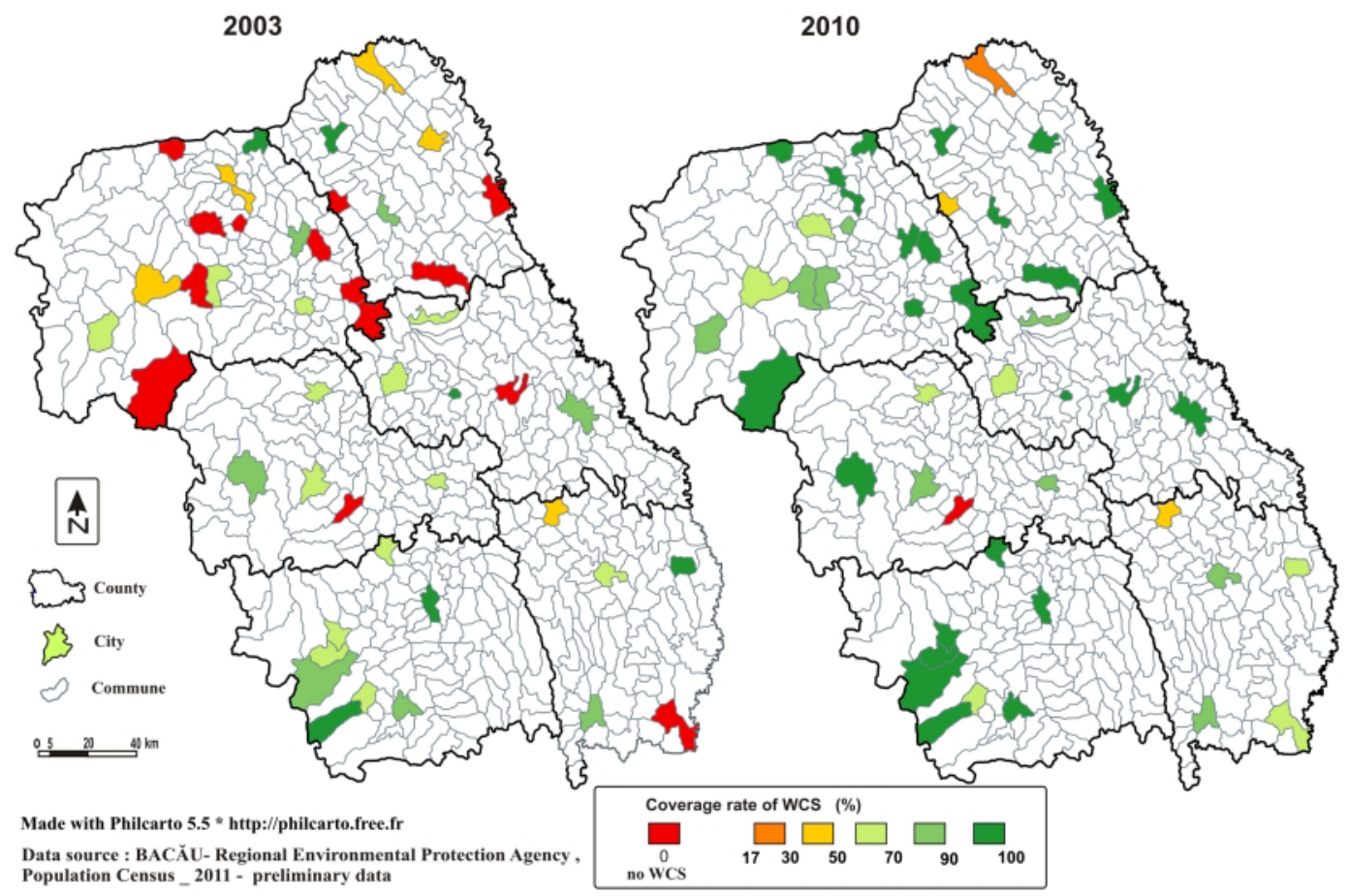

Fig. 1. Urban disparities in population access to WCS (2003 vs. 2010) 
values (\%): Piatra Neamț (67.29/62,44/ 86) Tg. Neamț (53.25/46.91/53.26), Roman (53.85/53.29/75.21), Bicaz (86.71/76.7/90), Vaslui (67.95/59.1/81), Bârlad (79.16/ 65,58/81,6), Huși (100/46.68/54.54), Negrești (40.31/28.63/36.72) and Murgeni (0/55.91/68.5).

A modern integrated waste management system is operational in Piatra Neamt since 2007 but nevertheless the WCS doesn't cover the full population according to waste statistics. Also, the small cities recently implemented waste management services after the closure of improper dumpsites (deadline 16 JULY, 2009) which contribute to a significant improvement rate of WCS in 2010 compared to 2003. Roznov was the only city from North-East region without a organized WCS in 2010 but new waste management facilities (transfer station, separate collection) are operational since 2011. The amounts of uncollected household waste by urban municipalities $\left(Q_{w u}\right)$ could be a key indicator in order to examine the vulnerability of urban areas to illegal dumping.

This indicator depends on the reliable data provided by statistics regarding the number of inhabitants served by waste operators. The higher rate of WCS from 2010 compared to 2003 it is also reflected in lower values of Qwu for most urban areas from study area. Old operational systems from 2003 encouraged the bad practices such as illegal dumping of waste within urban areas, on riverbanks or on floodplains in the proximity , uncontrolled burning etc. Partially coverage rate of WCS from densely cities such as county capitals led to higher values of $Q_{w u}$ than other cities with poor waste management facilities. Also, demographic features of cities play an important role on impact assessment of illegal dumping. The values of $\mathrm{Q}_{\mathrm{wu}}$ ranging between 300 t/yr - 1500 t/yr are specific to new urban areas which were lacking by WCS in 2003. Then, most vulnerable to illegal dumping were larger cities (over 3000 t/yr) such as Iasi, Pașcani, Piatra Neamț, Roman, Vaslui, Bârlad, Suceava and Botoșani. The mixed waste collected were disposed in

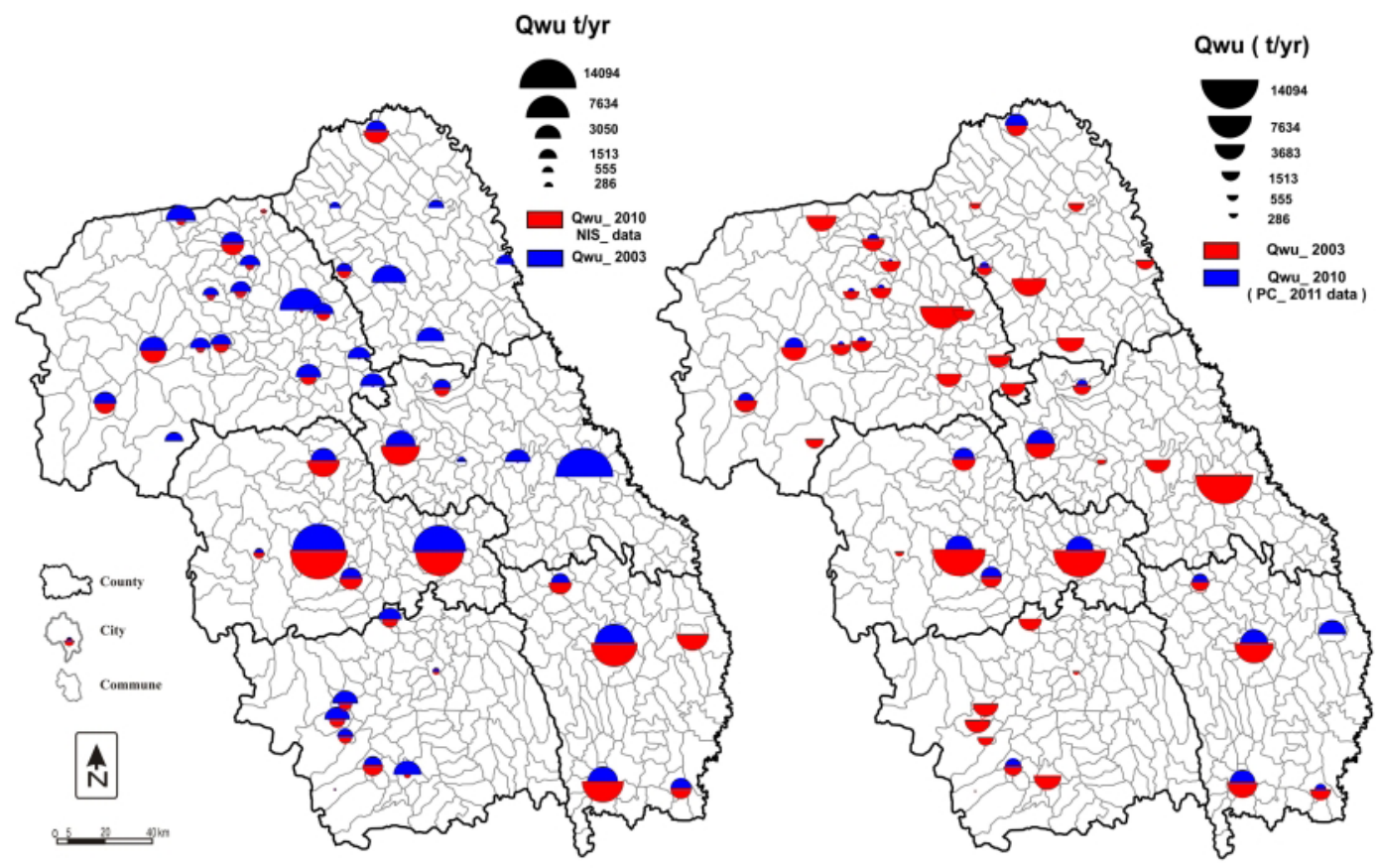

Fig. 2. Geographical distribution of Qwu in urban areas (2003 vs 2010) 


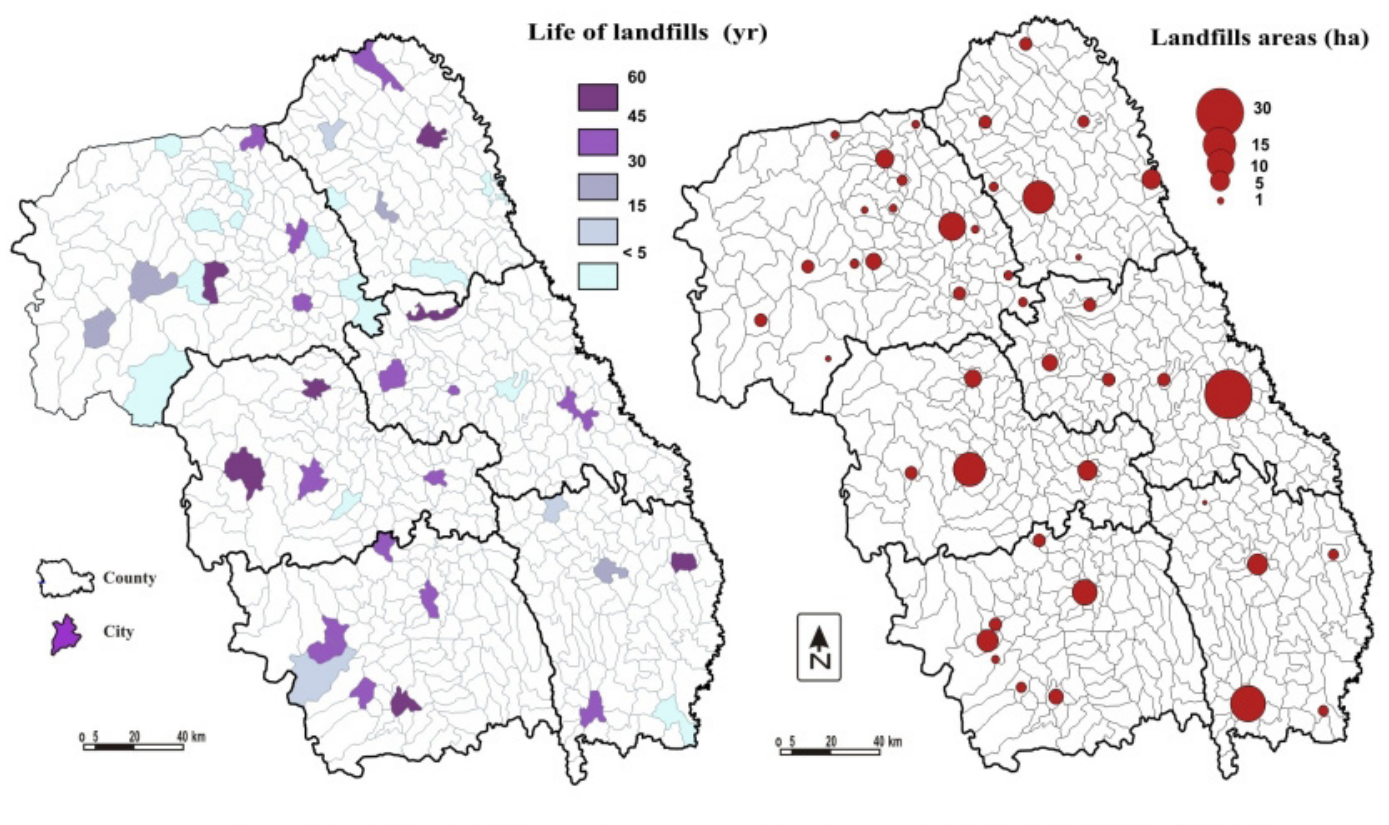

Made with Philcarto 5.5 * http://philcarto.free.fr

Data source : Bacau - Regional Environmental Protection Agency

Fig. 3. The surfaces ( ha) and life of non-compliant landfills from urban areas

non-compliant landfills frequently located in the proximity of built-up areas (Mihai, et al., 2013). These large dumpsites (over 10 ha) were or still are operational over 30 years, even 45 years in some cases, being major sources of complex pollution (see Fig. 3). Large investments in waste management sector is needed to replace these old sites. Municipalities depend on EU funds in order to implement the new integrated waste management systems at county scale. Regular WCS within densely areas (blocks of 10 or 4 levels) are provided in larger cities but these are more scarcely seen in households sectors or rural localities annexed to ATU of cities (eg. Bicaz).

Although, the urban population is not fully covered by WCS, in reality, most of the urban waste generated from county capitals were collected and disposed in non-compliant landfills. The losses of operational costs (due to the population which didn't pay the sanitation fee) were supported from local budget even if their wastes were discharged in containers or bins from city. Bad management led to poor quality of WCS which facilitated the mixed collection and illegal dumping of waste in peripheral areas.

Newurbanareas(lesspopulated than larger cities) had no proper waste management facilities until 2009. The amounts of waste generated were often disposed on improper sites from surroundings. Because the lack of an organized waste collection system, these dumpsites were frequently small $(<1$ ha) spontaneous, temporarily (short life) and uncontrolled. These dumpsites had the same features as ones from rural areas, being closed and rehabilitated under the same procedure (Mihai et al., 2012b). Recents improvements of urban waste management infrastructure is more significant than the extension of WCS from some urban areas particularly in Neamt County (despite of high values of $\mathrm{Q}_{\mathrm{wu}}$ indicator). Caution must be employed for analysis of $Q_{w u}$ indicator in 2010 due to overestimation of stable population by NIS database, this fact it is also revealed through comparative analysis of results between two data source as shown in Figure 2.

Readjustment of population data from 2010 is imperative, the differences between NIS_2010 and PC_2011 are significant for cities of Neamt (30241.91/10757.15 t/yr) 
and Vaslui counties (24198.07/10150.69 t/yr) as follows: Piatra Neamt (13884.91/ 3361.56 t/yr), Roman (9672.35/ 3194 t/yr), Roznov (2215.769/1886.88 t/yr), Tg. Neamt (4011.35/2314.498 t/yr), Vaslui (8866.94/ 3002.49 t/yr ), Bârlad (7349.82/2427.448 t/yr), Huși (4205.72/3106.15 t/yr), Murgeni (1823.837/461.494 t/yr), Negrești (1951.743/1153.106 t/yr). Separate collection facilities are already ordinary in current waste management options at North-East Region level but the treatment and recycling facilities are in early stages. Current systems of waste collection including the new ones prove to be ineffective so far in terms of waste hierarchy concept (Mihai, 2013) and illegal dumping is still present in some urban areas.

\section{Conclusion}

Poor solid waste management facilities led to a partially extension of WCS within urban areas in 2003. In this context, larger cities were most vulnerable to waste pollution due to :

- the illegal dumping from outskirts of cities (highest values of $\mathrm{Q}_{\mathrm{wu}}$ indicator),

- non-compliant landfills,

- mixed waste collection

- poor recycling rates.

Spatial analysis reveals various trends of WCS at urban scale in a regional context between pre-accession and post-accession period. This sector is facing the challenges imposed by EU Directives and on the other hand, the transition from public to private waste operators. Also, the $Q_{w u}$ indicator aims a quantitative assessment of potential waste which could be uncontrolled disposed at urban scale. Furthermore, demographic features of cities highlight the links between the WCS rate and $Q_{w u}$ indicator. Major urban disparities reflected on regional scale outline the past and current dysfunctions of municipal waste management sector.

\section{References}

Alwaeli, M. (2010): The impact of product charges and EU directives on the level of packaging waste recycling in Poland, Resources, Conservation and Recycling, 54: 609-614

Koci, V. Trecakova, T. (2011): Mixed municipal waste management in the Czech Republic from the point of view of the LCA method, Int J Life Cycle Assess, 16: 113-124

Mihai, F. C. (2013): Performance assessment method of urban waste management systems from NeamțCounty, Romania, Present Environement and Sustainable Development, 7 (1): 159-166

Mihai, F. C. - Apostol L. - Ursu, A. - Ichim, P. (2013): Landfills as anthropogenic landforms in urban environment from Neamţ county. AES Bioflux 5 (2): 100-108

Mihai, F. C. - Lămășanu, A. - Apostol, L. (2012): Regional disparities in urban population access to sanitation services. Case study:Romania Mediterranean Journal of Social Sciences, Special issue 3 (6): 273-279

Mihai, F. C. - Apostol, L. (2012): Disparities in municipal waste management across EU-27. A geographical approach. Present Environment and Sustainable Development, 6 (1): 169-180

Mihai, F. C. - Ghiurca, A. - Lamasanu, A. (2011): Estimation of urban waste generated and uncollected in Romania, Analele Universitati Oradea, Fascicula:Protectia Mediului, 17 (2): 719-724

Mihai, F. C. (2012): Population access to waste collection services: urban vs rural areas in Romania, Bulletin of University of Agricultural Sciences and Veterinary Medicine. Agriculture, 69 (2): 464-466, short com.

Mihai, F. C. - Apostol, L. - Ghiurca, A. A. - Lamașanu A. - Bănică, A. (2012): Geographical distribution of rural dumpsites in North-East Region from Romania, Proceedings of 12th International Multidisciplinary Scientific GeoConference SGEM, Albena, Bulgaria, (5),pp. 447-452, DOI: 10.5593/sgem2012/s20.v5060

Mihai, F. C. (2012): Geography of waste as a new approach in waste management study, Papers of "Dimitrie Cantemir" Geographical Seminar, 33: $39-46$

Orosz, Z. - Fazekas, I. (2008): Challenges of municipal waste management in Hungary. AGD Landscape \& Environment 2 (1): 78-85

Regional Environment Protection Agency of Bacau (2006) Regional waste management plan in North-East Region, http://www.anpm.ro/ articole/cadrul_general-140 